\title{
Implementasi pendidikan multikultural berbasis nilai ketuhanan dan nilai persatuan untuk peningkatan karakter toleransi
}

\author{
Arum Putri Pertiwi, ${ }^{a, 1^{*}}$ Uswatun Hasanah ${ }^{b, 2}$ \\ ${ }^{a}$ Pascasarjana UNY, Yogyakarta \\ ${ }^{\mathrm{b}}$ SMP Negeri 4 Sungailiat, Sungailiat \\ ${ }^{1}$ arumpertiwi06@gmail.com, ${ }^{2}$ uswatunhasanah120@yahoo.com \\ * Korespondensi penulis
}

\begin{abstract}
ABSTRAK
Pendidikan multikultural merupakan sarana untuk mendidik seseorang agar dapat hidup berdampingan dengan orang lain dengan latar belakang yang berbeda untuk mencapai kerukunan, ketertiban, dan kedamaian. SMP Negeri 4 Sungailiat merupakan salah satu sekolah menengah pertama yang memasukkan studi kasus tentang penggabungan kelas. Ada dua jenis kelas yang ada di SMP Negeri 4 Sungailiat yaitu kelas yang terdiri dari beberapa agama dan kelas yang hanya terdiri dari satu agama saja. Hal ini bertujuan untuk proses pendidikan multikultural yang berbasis nilai ketuhanan dan nilai persatuan dalam peningkatan karakter toleransi. Tujuan penelitian untuk menganalisis tentang strategi implementasi terkait pendidikan multikultural berbasis nilai ketuhanan dan persatuan dalam peningkatan kerakter toleransi di SMP Negeri 4 Sungailiat. Penelitian ini menggunakan pendekatan kualitatif- deskriptif. Penelitian dilaksanakan di SMP Negeri 4 Sungailiat. Data dikumpulkan dengan teknik wawancara dan teknik observasi. Subjek penelitian ada enam orang. Proses analisis data terdiri dari tahap pengumpulan data, reduksi data, penyajian data, dan penarikan kesimpulan. Hasil penelitian yang telah dilakukan bahwa adanya suatu strategi untuk implementasi pendidikan karakter berbasis nilai ketuhanan dan nilai persatuan untuk peningkatan karakter toleransi. Adapun strategi implementasi yang dilakukan oleh SMP Negeri 4 Sungailiat yaitu penanaman kognitif tentang pendidikan multikultural berbasis nilai ketuhanan dan nilai persatuan, sikap terkait permasalahan pendidikan multikultural berbasis nilai ketuhanan dan nilai persatuan, tindakan dari aktualiasasi proses pendidikan multikultural berbasis nilai ketuhanan dan nilai persatuan, pembiasaan untuk bertindak pendidikan multikultural berbasis nilai ketuhanan dan nilai persatuan, dan terbentuknya karakter toleransi.
\end{abstract}

Kata kunci: pendidikan multikultural, nilai ketuhanan, nilai persatuan, toleransi

\begin{abstract}
Multicultural education is a means to educate someone to be able to live side by side with others with different backgrounds to achieve harmony, order, and peace. Sungailiat of Middle School 4 is one of the junior high schools that includes case studies on class integration. There are two types of classes, namely a class consisting of several religions and a class consisting of only one religion. It aims to process multicultural education based on the divine value and the value of unity in enhancing the character of tolerance. The purpose of the study was to analyze implementation strategies related to the multicultural education based on the value of God and unity in increasing tolerance characteristics in Sungailiat of Middle School 4. This research uses a qualitative-descriptive approach. The study was conducted at Sungailiat of Middle School 4. Data collected by interview and observation techniques. The research subjects were six people. The process of data analysis consists of the stages of data collection, data reduction, data presentation, and drawing conclusions. The results of the research have been carried out that there is a strategy for the implementation of character education based on the value of God and the value of unity to increase the character of tolerance. The implementation strategy undertaken by Sungailiat of Middle School 4 is cognitive planting about multicultural education based on divine values and unity values, attitudes related to multicultural education problems based on divinity values and unity values, actions of actualizing multicultural education processes based on divinity values and unity values, habituation to acting multicultural education based on the divine and united values, and the formation of the character of tolerance.
\end{abstract}

Keywords: multicultural education, the value of God, the value of unity, tolerance

Copyright (C2020 Universitas Ahmad Dahlan, All Right Reserved 


\section{PENDAHULUAN}

Indonesia memiliki aneka multikultral mulai dari keragaman suku, bahasa, agama, golongan, dan budaya. Kelompok struktural pada masyarakat multikultural dapat diidentifikasi menjadi enam kategori antara lain suku, ras, bahasa, status sosial, religi, dan letak geografis (Bunyamin, 2016). Multikultural merupakan suatu kondisi dimana masyarakat hidup dengan berbagai latar belakang yang berbeda-beda, namun masyarakat harus tetap hidup rukun, tertib, dan damai sesuai dengan aturan yang berlaku. Keberagaman di Indonesia bukan hanya sebatas pengetahuan tentang kekayaan saja melainkan suatu sikap dan tindakan agar masyarakat mampu mempertahankan dan melestarikan pada generasi selanjutnya, maka perlu adanya suatu pendidikan tentang keragaman. Pendidikan multikultural merupakan salah satu solusi untuk memberikan pemahaman dan penyikapan tentang keragaman.

Pendidikan multikultural merupakan suatu sarana untuk internalisasi keragaman tentang budaya, ras, gender, etnik, agama, status sosial, agama, dan ekonomi. Keragaman bukanlah suatu permasalahan yang harus diperdebatkan. Namun, keragaman menjadi suatu kekayaan bagi bangsa Indonesia. Adapun pemicu konflik dalam keberagaman antara lain prasangka historis, diskriminasi, dan perasaan superioritas in-group feeling yang berlebihan terhadap pihak lain, perbedaan kepentingan, keinginan visi, keyakinan dan tradisi, politik, dan ideologi (Bunyamin, 2016; Puwasito, 2003).

Pada masa kini, masih ada orang yang distoleran tekait keragaman seperti tidak mau menghargai perbedaan suku, ras, bahasa, status sosial, dan religi. Padahal Undang-Undang Sistem Pendidikan Nasional Nomor 20 tahun 2003 menyatakan bahwa pendidikan adalah usaha sadar dan terencana untuk mewujudkan suasana belajar dan proses pembelajaran agar peserta didik secara aktif dapat mengembangkan potensi dirinya untuk memiliki kekuatan spiriual, pengendalian diri, kepribadian, kecerdasan, akhlak mulia, serta keterampilan yang diperlukan dirinya, masyarakat, bangsa, dan negara. Hal ini menunjukan bahwa proses pendidikan belum mampu terlaksana sebagaimana mestinya.

Nilai ketuhanan merupakan nilai yang pertama dan utama pada nilai-nilai Pancasila. Perwujudan nilai ketuhanan harus didasarkan pada ketuhanan Yang Masa Esa. Namun, belum semua orang memahami makna ketuhanan pada sila pertama sesuai dengan kepercayaan yang dianutnya. Setiap warga negara wajib berketuhanan Yang Maha Esa, bersikap saling menghormati dan bekerjasama antar umat beragama perlu diimplementasikan dalam kehidupan berbangsa dan bernegara. Hal ini bertujuan untuk menghindari permasalahan terkait perbedaan beragama.

Selanjutnya, semboyan Bhinneka Tunggal Ika yang artinya berbeda-beda tetapi tetap satu jua sangat penting ditanamkan dalam hati bangsa Indonesia. Indonesia yang masyarakatnya heterogen harus memiliki semboyan untuk menciptakan rasa bersatu. Persatuan merupakan berkumpulnya macam-macam corak dari berbagai kalangan, ras, budaya, dan adat istiadat dalam masyarakat yang bersatu dengan serasi. Di Indonesia kita sering mendapatkan kasus yang berhubungan dengan disintegrasi masyarakat. Contohnya perang antar suku, kasus Organisasi Papua Merdeka (OPM), dan kasus bullying. Sehingga, perlu memahami makna sila ketiga "persatuan Indonesia" dengan baik agar persatuan dan kesatuan bangsa Indonesia dapat terus terjaga dengan baik tanpa perselisihan.

Konflik seperti aksi teror, kekerasan, dan masalah berlatar agama yang menimpa berbagai kelompok agama berbeda, biasanya, terjadinya karena tidak mau menerima pendapat orang lain dan menganggap pendapat atau ajarannya yang paling benar. Perlunya moderasi agama untuk meredam hal tersebut. Moderasi agama merupakan suatu cara pandang, sikap, dan berperilaku yang tidak terlalu fanatik terkait agama yang dianut. Beribadah merupakan suatu kewajiban individu dengan Tuhan, tetapi ketika sudah berinteraksi dengan sesama makhluk hidup yang lain harus tetap mengutamakan kefaiaman dan ketertiban bersama. Moderasi beragama sesungguhnya merupakan kunci terciptanya toleransi dan kerukunan, baik di tingkat lokal, nasional, maupun global.

SMP Negeri 4 Sungailiat merupakan salah satu sekolah menengah pertama yang memasukkan studi kasus tentang penggabungan kelas. Ada dua jenis kelas yang ada di SMP Negeri 4 Sungailiat yaitu kelas yang terdiri dari beberapa agama dan kelas yang hanya terdiri dari satu agama saja. Ada beberapa penelitian yang sudah dilakukan. Penelitian yang sudah dilakukan banyak yang membahas tentang pendidikan multikultural (Bunyamin, 2016), nilai ketuhanan (Rube'i \& Utami, 2018), nilai persatuan (Hanafi, 2018), dan karakter toleransi (Nugraha \& Firmansyah, 2019) secara terpisah tetapi penelitian ini membahas pendidikan multikultural, nilai ketuhanan, nilai persatuan dan karakter toleransi menjadi satu kesatuan yang utuh. 
Penelitian ini merupakan salah satu strategi dalam upaya peningkatan karakter tolerasi di SMP Negeri 4 Sungailiat melalui implementasi pendidikan multikultural berbasis nilai ketuhanan dan persatuan. Masalah ketuhanan dan persatuan di dalam masyarakat Indonesia yang plural sangat membutuhkan pendidikan multikultural. Melalui pendidikan multikultural kita dapat memadukan konsep moderasi di dalamnya. Sebab, moderasi beragama bisa jadi bukan pilihan, melainkan keharusan. Konsep moderasi mampu menerapkan nilai ketuhanan dan persatuan guna meningkatkan karakter toleransi. Moderasi dapat menolak ekstremisme dan liberalisme dalam beragama. Hal tersebut kunci keseimbangan, demi terpeliharanya peradaban dan terciptanya perdamaian. Dengan cara inilah masing-masing umat beragama dapat memperlakukan orang lain secara terhormat, menerima perbedaan, serta hidup bersama dalam damai dan harmoni. Tujuan penelitian untuk menganalisis tentang srategi implementasi terkait pendidikan multikultural berbasis nilai ketuhanan dan persatuan untuk peningkatan kerakter di SMP Negeri 4 Sungailiat.

\section{METODE}

Penelitian ini menggunakan pendekatan kualitatif-deskriptif. Penelitian dilaksanakan di SMP Negeri 4 Sungailiat, Kepulauan Bangka Belitung. Lokasi penelitian ini di Jalan Gajah Mada Air Kenanga Kecamatan Sungailiat kabupaten Bangka Provinsi Kepulauan Bangka Belitung. Data dikumpulkan dengan teknik wawancara dan teknik observasi. Subjek penelitian ada enam orang yang terdiri dari kepala sekolah, guru Pendidikan Agama Islam, guru PPKn, dan tiga peserta didik. Data penelitian tervalidasi dengan triangulasi sumber dan triangulasi teknik. Proses analisis data terdiri dari tahap pengumpulan data, reduksi data, penyajian data, dan penarikan kesimpulan.

\section{HASIL DAN PEMBAHASAN}

Menurut Undang-Undang No. 20 Tahun 2003 menyatakan pendidikan merupakan usaha sadar dan terencana untuk mewujudkan suasana belajar dan proses pembelajaran yang bertujuan agar peserta didik dapat mengembangkan potensi dirinya untuk memiliki kekuatan spiritual, pengendalian diri, kepribadian, kecerdasan, akhlak mulia, dan keterampilan untuk dirinya, masyarakat, bangsa, dan negara. Undang-Undang Dasar 1945, Pasal 31 menyatakan bahwa setiap individu memiliki hak untuk memperoleh pendidikan. Proses pendidikan di sekolah memiliki fungsi untuk mengembangkan kemampuan, membentuk watak dan peradan yang bermartabat. Hal ini selaras dengan tujuan dari pendidikan nasional yaitu membentuk manusia yang beriman dan bertakwa kepada Tuhan Yang Maha Esa, berakhlak mulia, sehat, berilmu, cakap, kreatif, mandiri, demokratis dan bertanggung jawab.

Pendidikan tidak terlepas dengan kata belajar. Pierre Bourdieu menjelaskan belajar dalam teori habitus. Dalam teorinya dijelaskan bahwa perilaku seseorang terbentuk melalui interaksi atau dialektika antara struktur sosial atau lingkungan (faktor obyektif) dengan individu (faktor subyektif) melalui medisposisinya secara sukarela (natural). Artinya individu itu sadar dalam berinteraksi tanpa melihat perbedaan dan tanpa paksaan. Kemudian kesadaran individu dapat dibentuk pula melalui proses pedagogik (pendidikan) dalam bentuk nyata yaitu sekolah.

Pendidikan multikultural merupakan sarana untuk mendidik seseorang agar dapat hidup berdampingan dengan orang lain dengan latar belakang yang berbeda untuk mencapai kerukunan, ketertiban, dan kedamaian. Pendidikan multikultural mampu membuat seseorang untuk berinteraksi dengan latar belakang kultur yang berbeda-beda (Bunyamin, 2016).

Bangsa Indonesia terdiri dari banyak etnik, agama, ras, dan bahasa. Namun, setiap individu harus dapat hidup dan berinteraksi dengan keragaman yang ada. Hal ini dapat terealisasikan apabila setiap individu mampu memiliki sikap toleransi (Rosyada, 2014). Keragaman yang ada dapat dijadikan sebagai sumber kekayaan bangsa Indonesia.

Nilai Ketuhanan adalah salah satu dari nilainilai Pancasila. Nilai-nilai Pancasila menjadi landasan dasar dan pedoman untuk bertindak di kehidupan sehar-hari (Asmaroini, 2016). Manusia sebagai makhluk Tuhan harus berlandaskan pada nilai ketuhanan. Hal ini menunjukan bahwa semua ucapan dan tindakan akan ada pertanggung jawaban, sehingga setiap manusia harus berhatihati dalam berucap dan bertindak.

Ketuhanan Yang Maha Esa bukan hanya sebatas menghormati perbedaan agama saja tetapi menuju ke jalan kebenaran, keadilan, kebaikan, kejujuran, dan persaudaraan (Pattipeilohy, 2018). Berketuhanan yang welas asih bertujuan untuk menghargai dan mencintai sesama umat beragama (Latif, 2014). Ketuhanan Yang Maha Esa berkaitan tentang individu sebagai makhluk Tuhan. Setiap individu memiliki keyakinan tentang Ketuhanan sesuai dengan kepercayaan masing-masing. Nilai Ketuhanan Yang Maha Esa 
bertujuan agar setiap perbuatan individu harus berlandaskan pada Ketuhanan Yang Maha Esa.

Pengimplementasian nilai ketuhanan dapat meningkatan kecerdasan spiritual (Shofiyuddin, 2020). Prinsip Ketuhanan Yang Maha Esa antara lain: ketaqwaan hanya kepada Tuhan Yang Maha Esa, kebebasan beragama merupakan hak asasi bagi manusia, adanya karakter toleransi, adanya rasa cinta kepada semua ciptaan Tuhan, terutama manusia (Wiyono, 2013). Hal ini selaras dengan pendapat Darmadi (2014) yang menyatakan bahwa perlunya pedoman penghayatan dan pengamalan nilai ketuhanan, yaitu: 1) Percaya dan takwa kepada Tuhan Yang Maha Esa sesuai agama; 2) Hormat dan bekerja sama antar setiap pemeluk agama; 3) Saling menghormati dalam menjalankan ibadah; 4). Tidak memaksakan suatu agama kepada orang lain. Pedoman penghayatan dan pengamalan nilai ketuhanan dijadikan sebagai aturan dalam berinteraksi, sehingga terhindar dari tindakan distoleran.

Nilai Persatuan menjelaskan tentang konsepsi persatuan yang utuh tanpa terpecah belah dengan bermacam perbedaan. Nilai persatuan merupakan perwujudan dari makhluk individu dan makhluk sosial dimana setiap orang harus dapat mengaktualisasikan dirinya sesuai dengan kondisi, situasi, dan kebutuhan. Implementasi dari niali persatuan yaitu perlu adanya toleransi dan kurukunan dalam perbedan agama, suku, bahasa, budaya (Hanafi, 2018).

Nilai persatuan berdasarkan pada asas kekeluargaan dan tolong-menolong Adapun prinsip nilai persatuan yaitu persatuan, kebersamaan, nasionalisme, dan Bhinneka Tunggal Ika (Wiyono, 2013). Pengimplementasian nilai persatuan harus berlandaskan pada rasa cinta tanah air, menjalin persatuan dalam keragaman, mengutamakan kepentingan umum, dan mengembangkan gotongroyong dan kekeluargaan (Latif, 2014).

Sekolah merupakan suatu sarana untuk penanaman nilai persatuan. Sekolah bukan hanya sebagai pendidikan formal yang memberikan keterampilan kognitif saja tetapi keterampilan afektif dan psikomotorik dapat diperoleh oleh peserta didik. Ada beberapa upaya sekolah dalam internalisasi nilai persatuan yaitu nilai persatuan terintegrasi dalam mata pelajaran, nilai persatuan terintegrasi dalam muatan lokal, nilai persatuan terintegrasi dalam kegiatan pengembangan diri (Yasa et al., 2019).

Toleransi merupakan kemampuan untuk memperlakukan orang lain dengan baik, menghormati sifat dasar, keyakinan, dan perilaku seseorang. Tindakan toleransi perlu adanya pembiasaan secara terus-menerus agar terbentuknya karakter toleransi.

Konsep pendidikan multikultural berbasis nilai ketuhanan dan nilai persatuan untuk peningkatan karakter toleransi yaitu suatu proses internalisasi tentang pendidikan keberagaman. Proses pendidikan keberagaman yang harus berlandaskan pada nilai Ketuhanan dan nilai persatuan guna untuk terbentuknya karakter toleransi

SMP Negeri 4 Sungailiat merupakan salah satu sekolah menengah pertama yang memasukkan studi kasus tentang penggabungan kelas. Ada dua jenis kelas yang ada di SMP Negeri 4 Sungailiat yaitu kelas yang terdiri dari beberapa agama dan kelas yang hanya terdiri dari satu agama saja. Hal ini bertujuan agar mempermudah guru agama dalam menyampaikan agama. SMP Negeri 4 Sungailiat tetap melakukan proses pendidikan multikultural. Keberagaman merupakan suatu rahmat dari Tuhan Yang Maha Esa dan cara menyikapi perbedaan bukan pada intoleransi, memperdebatkan perbedaan yang ada dan melakukan tindakan-tindkaan kekerasan (Lestari, 2015).

Adapun temuan dari penelitian ini antara lain perlunya penanaman kognitif tentang pendidikan multikultural berbasis nilai ketuhanan dan nilai persatuan, sikap terkait permasalahan pendidikan multikultural berbasis nilai ketuhanan dan nilai persatuan, tindakan dari aktualisasi proses pendidikan multikultural berbasis nilai ketuhanan dan nilai persatuan, pembiasaan untuk bertindak berdasarkan pendidikan multikultural yang berbasis nilai ketuhanan dan nilai persatuan, terbentuknya karakter toleransi.

\section{Kognitif tentang pendidikan multikultural berbasis nilai ketuhanan dan nilai persatuan}

SMP Negeri 4 Sungailiat melatih peserta didik untuk memiliki kognitif tentang pendidikan multikultural berbasis nilai ketuhanan dan nilai persatuan. Hal ini dilakukan dengan cara Peserta didik terinternalisasi dengan konsep pendidikan nilai ketuhanan dan nilai persatuan. Peserta didik

\section{Sikap terkait permasalahan pendidikan multikultural berbasis nilai ketuhanan dan nilai persatuan}

Ketika peserta didik sudah mengolah dan memahami nilai ketuhanan dan persatuan, maka akan timbul sikap di dalam dirinya. Sikap untuk bertindak berdasarkan pada pemahaman.

Tindakan dari aktualiasasi proses pendidikan multikultural berbasis nilai ketuhanan dan nilai persatuan 
Guru-guru SMP Negeri 4 Sungailiat menjadi role model untuk peserta didik. Guru-guru ikut terlibat langsung dalam kegiatan di sekolah seperti ikut kerja bakti, upacara, senam dan hari besar umat beragama. Hal ini bertujuan agar peserta didik mampu menerapkan tindakan toleransi di lingkungan sekolah. Peserta didik harus mengikuti kegiatan di sekolah. Apabila ada peserta didik yang tidak mengikuti kegiatan di sekolah, maka pihak sekolah akan melakukan pembinaan kepada peserta didik agar mereka mau mengikuti kegiatan di sekolah. Tujuan dari kegiatan di sekolah adalah agar setiap peserta didik dapat mengetahui semua keragaman yang ada di sekolah dan penanaman nilai persatuan.

Proses penanaman nilai Ketuhanan yang dilakukan oleh SMP Negeri 4 Sungailiat dengan cara peserta didik diwajibkan membaca kitab suci agama yang dianutnya dan apabila ada acara keagamaan, agama yang lain dapat mengikuti kegiatan tetapi hanya sebatas menghargai saja.

\section{Pembiasaan untuk bertindak berdasarkan pendidikan multikultural berbasis nilai ketuhanan dan nilai persatuan}

Kempat, pembiasaan untuk bertindak berdasarkan pada pendidikan multikultural yang berbasis nilai ketuhanan dan nilai persatuan. Pada tahap ini, orientasi tindakan peserta didik berubah yang mulai dari adanya paksaan dan hukum menjadi kesadaran dari dirinya sendiri. Peserta didik menyadri bahwa dirinya adalah makhluk tuhan dan makhluk sosial sehingga harus mnerapkan nilai ketuhanan dan persatuan.

\section{Terbentuknya karakter toleransi}

Karakter toleransi terbentuk dari proses pembinaan yang dilakukan dengan cara pembinaan kognitif tentang pendidikan multikultural berbasis nilai ketuhanan dan nilai persatuan, adanya sikap terkait permasalahan pendidikan multikultural yang berbasis dari nilai ketuhanan dan nilai persatuan, adanya tindakan yang dilakukan akibat dari aktualisasi pendidikan multikultural yang berbasis nilai ketuhanan dan nilai persatuan, serta pembiasaan untuk bertindak berdasarkan pada pendidikan multikultral yang berbasis nilai ketuhanan dan nilai persatuan.

\section{KESIMPULAN}

Berdasarkan hasil penelitian dan pembahasan, secara umum penelitian dapat disimpulkan bahwa perlu adanya strategi untuk implementasi pendidikan karakter berbasis nilai ketuhanan dan nilai persatuan untuk peningkatan karakter toleransi di SMP Negeri 4 Sungailiat Hal ini dapat terwujud apabila lima tahapan terlaksana dengan baik. Adapun lima tahapan implementasi pendidikan multikultural berbasis nilai ketuhana dan persatuan untuk peningkatan karakter toleransi antara lainpembinaan kognitif tentang pendidikan multikultural berbasis nilai ketuhanan dan nilai persatuan, adanya sikap terkait permasalahan pendidikan multikultural yang berbasis dari nilai ketuhanan dan nilai persatuan, adanya tindakan yang dilakukan akibat dari aktualisasi pendidikan multikultural yang berbasis nilai ketuhanan dan nilai persatuan, serta pembiasaan untuk bertindak berdasarkan pada pendidikan multikultral yang berbasis nilai ketuhanan dan nilai persatuan.

\section{UCAPAN TERIMA KASIH}

Ucapan terima kasih kepada pihak SMP Negeri 4 Sungailiat terutama pada kepala sekolah, guru Pendidikan Agama Islam, guru PPKn, dan para siswa yang telah berkenan untuk bersedia menjadi narasumber dan membantu dalam pengambilan data.

\section{DAFTAR PUSTAKA}

Asmaroini, A. P. (2016). Implementasi NilaiNilai Pancasila Bagi Siswa Di Era Globalisasi. Citizenship Jurnal Pancasila dan Kewarganegaraan, 4(2), 440. https://doi.org/10.25273/citizenship.v4i2. 1077

Bunyamin, B. (2016). Pendidikan Multikultural Menuju Masyarakat Bermartabat. Jurnal Pendidikan Islam, 7(2), 1-20.

Darmadi, H. (2014). Pendidikan Pancasila, Konsep Dasar dan Implementasi. Alfabeta.

Hanafi. (2018). Hakekat nilai persatuan dalam konteks Indonesia (Sebuah tinjauan kontekstual positif Sila ketiga Pancasila). Jurnal Ilmiah Pendidikan Pancasila dan Kewarganegaraan, 3(1), 56-63. https://doi.org/10.17977/um019v3i12018p 056

Latif, Y. (2014). Mata air keteladanan: Pancasila dalam perbuatan. Penerbit Mizan.

Lestari, G. (2015). Bhinnekha Tunggal Ika: Khasanah Multikultural. Jurnal Pendidikan Pancasila dan Kewarganegaraan, I(Februari), 31-37.

Nugraha, Y., \& Firmansyah, Y. (2019). Karakter toleransi beragama dalam sudut pandang generasi milenial. Jurnal Moral Kemasyarakatan, 4(2), 69-76. https://doi.org/10.21067/jmk 
Arum Putri Pertiwi, dkk. Implementasi pendidikan multikultural berbasis nilai ketuhanan dan nilai persatuan untuk peningkatan karakter toleransi

Pattipeilohy, S. Y. E. (2018). Ketuhanan yang BerkebudayaanKetuhanan yang Berkebudayaan: Memahami Pancasila sebagai Model Interkulturalitas. Gema Teologika, 3(2), 121. https://doi.org/10.21460/gema.2018.32.36 3

Puwasito, A. (2003). Komunikasi Multikultural. Muhammadiyah University Press.

Rosyada, D. (2014). Pendidikan Multikultural Di Indonesia Sebuah Pandangan Konsepsional. SOSIO DIDAKTIKA: Social Science Education Journal, 1(1). https://doi.org/10.15408/sd.v1i1.1200

Rube'i, M. A., \& Utami, D. (2018). Penanaman sila Ketuhanan Yang Maha Esa pada Pelajaran Pendidikan Pancasila dan
Kewarganegaraan Kelas XI SMA Negeri 1 Toho Kabupaten Mempawah. Pendidikan Kewarganegaraan, 2(1), 309-318.

Shofiyuddin, A. (2020). Model pendidikan spiritual dalam mengembangkan karakter anak. Darajat: Jurnal PAI, 3(1), 38-50.

Wiyono, S. (2013). Reaktualisasi Pancasila dalam Kehidupan Berbangsa dan Bernegara. Universitas Wisnuwardhana Malang Press.

Yasa, I. K. D., Dahlan, \& Yuliatin. (2019). Upaya sekolah dalam internalisasi nilai persatuan pada siswa di SMA Katolik Kesuma Mataram. Jurnal Pendidikan Sosial Keberagaman, 6(1), 36-45. 